\title{
A Filosofia da História de Oswald de ANDRADE
}

\author{
Ulisses do Valle
}

\begin{abstract}
Oswald de Andrade (1890-1954) é normalmente conhecido como um dos poetas símbolo da primeira geração de modernistas brasileiros. Sua obra, entretanto, extravasa o já amplo espectro da poesia e atinge também outras formas de expressão que, no que se refere ao autor em questão, foram menos exploradas pela crítica. Outra forma muito utilizada pelo autor, além da poesia, do romance ficcional, do teatro e da crônica, foi o ensaio. Este trabalho pretende resgatar a dimensão ensaística do pensamento oswaldiano e nele investigar a existência de elementos que guardem afinidade com uma filosofia substantiva da história, sob a hipótese de que tais elementos se difundem em sua utopia política e mesmo em suas teorias estéticas, cujos manifestos Pau-Brasil (1924) e Antropófago (1928) são os exemplos mais conhecidos. Em a Crise da filosofia messiânica (1950), Oswald delineia a longa trajetória de ascensão e declínio da fase Patriarcal em paralelo a seu registro na literatura e no pensamento ocidental - processo que vai de Hesíodo e Ésquilo até Sartre. E, em A marcha das utopias (1953), Oswald tematiza a utopia como forma da experiência humana que reorienta nossa "credulidade" e "imaginação" para o possível, contra a ordem estabelecida. É a partir desses rastros que o trabalho que se segue delineará os elementos fundamentais da leitura filosófica da história empreendida pela utopia oswaldiana.
\end{abstract}




\section{I - O POEMA-ENSAIO DE OSWALD DE ANDRADE}

Existe uma diversidade bibliográfica enorme, embora relativamente tardia, a respeito da obra de Oswald de Andrade. E, mesmo que muitos críticos da obra de Oswald tenham reconhecido sua proximidade com o tema da história (CÂNDIDO, 2004; HELENA, 1985; CAMPOS, 1991; OLIVEIRA, 2002), nenhum concentrou atenção na visão de história que se pode destacar de seus ensaios. De fato, é bastante perceptível nos textos oswaldianos, principalmente em seus dois famosos manifestos $\mathrm{Pau}$ Brasil (1924) e Antropófago (1928), o projeto de uma desconstrução crítica da historiografia brasileira a partir do questionamento da constituição monológica e etnocêntrica da memória histórica condensada nas crônicas, nos monumentos e nos documentos coloniais. Nesses manifestos percebe-se o furor de uma vontade de escrever a história a contrapelo, de resgatar os signos e os significados extraídos da investigação das crônicas em sua ambivalência derivada dos conflitos e dos encontros nos quais sua escrita estava envolvida, restituindo à parte vencida - e obliterada na visão legada pelo vencedor - sua posição de sujeito, seu olhar sobre si mesmo. A crítica poética de Oswald exigia uma nova orientação historiográfica, que superasse o nativismo romântico fundado na aceitação acrítica das representações da colônia, feitas através dos olhos da metrópole portuguesa. Sua reorientação da historiografia em direção aos outros sujeitos que foram coisificados num processo de representação, exigiria, assim, uma nova codificação da memória histórica pré-processada nas fontes, com oque haveria consequências inclusive na dimensão cronológica da escrita historiográfica: a historiografia brasileira, nesse sentido, deveria começar não com a "descoberta de Cabral", mas com os atos que marcam a presença de um contradiscurso frente ao discurso colonizador, de uma reação dessacratória da parte invadida sobre a invasora. É a devoração do bispo Sardinha pelos índios Caetés que deveria marcar o início da história do Brasil.

Se o tema da história, em diversos aspectos e perspectivas, esteve presente nas diferentes fases do pensamento de Oswald, ele parece ter sido verticalizado e aprofundado em seus ensaios. Textos de aguda erudição filosófica, histórica, teológica e literária, os ensaios de Oswald estão longe de estabelecerem-se em consonância aos modelos tradicionais de ensaio filosófico entendido como gênero literário. Ao contrário, o estilo e a forma como foram escritos não apenas os destacam pela concisão, irreverência 
e agudez das sentenças que os compõem, como também favorecem e viabilizam a expressão e a constituição de um complexo conteúdo.

Os ensaios de Oswald, neste sentido, carregam uma diversidade de elementos estéticos que são trazidos da poesia (modernista) para um âmbito literário até então estranho a tais elementos expressivos. O humour, a sátira, o "estilo telegráfico", a "colagem" de citações que se ajustam poeticamente para produzir efeitos retóricos são elementos adaptados a uma vigorosa pretensão de síntese filosófica. O estilo telegráfico, feito de sentenças curtas e diretas, é no texto não só um artifício orientado à produção de um efeito estético no leitor, mas também um meio de condensar processos históricos de altíssima densidade e complexidade em proposições simples que, no entanto, representam o longo percurso de uma poderosa ideia.

O estilo telegráfico, nesse sentido, revela-se como uma imprescindível ferramenta expressiva que permite sintetizar numa mesma representação a amplitude do processo histórico que vai do Matriarcado à consolidação do Patriarcado. $\mathrm{O}$ ensaio quase todo é composto de parágrafos curtos, feitos com poucas frases, às vezes duas e até uma só, constituídas de modo direto por sentenças breves e declarativas que, frequentemente, condensam numa oração vertiginosos abismos da expressão filosófica. Oriundo da poesia modernista, o estilo telegráfico é atenuado no ensaio filosófico, muito embora não perca um papel essencial que consiste em ser o arremate de um raciocínio ou composição anterior e de maior densidade. Funciona, pois, como a batida de um martelo que sanciona o julgamento até então, por assim dizer, em aberto. Como quando, depois de exaltar os feitos bélicos e imperiais dos holandeses na era das navegações, Oswald (ANDRADE, 2011b, p. 276) conclui: "E vieram, no Brasil, tomar uma tunda tremenda de negros, mulatos, cafuzos e degradados”. Ou quando, depois de evidenciar a orientação ética do cristianismo primitivo a partir da figura de Cristo, declara: "É um deus de sindicato" (ANDRADE, 2011a, p. 146). Ou ainda quando tematiza as mudanças de consciência e valores implementadas pelo ascetismo protestante e sua afinidade com a racionalização da vida em torno do trabalho e da aquisição, e afirma: "O anglicanismo é uma teologia do tecido, depois do carvão" (p. 182).

Os ensaios de Oswald, neste sentido, são ensaios poéticos, isto é, escritos sem a sisudez de um tratado filosófico e que, mais do que isso, evidenciam e trazem à tona o caráter de poesia que subjaz mesmo à mais prolixa das prosas: a poesia, assim nos parece, era para Oswald a matriz 
de todos os gêneros literários e era, por isso, inseparável de cada um deles. Aquilo que Oswald já havia realizado, em termos de trabalho da forma, na poesia e no romance, ele também o faz com relação ao ensaio: isto é, subverte o padrão convencional que constitui os elementos estilísticos de expressão. Assim como Haroldo de Campos (2005) reconhecia em Serafim Ponte Grande um grande "não-livro", os ensaios de Oswald parecem extraordinários não-ensaios. Crise da filosofia messiânica, mais ainda que $A$ marcha das utopias, pode ser lido como um grande poema cujas estrofes se organizam de modo fragmentário, incompleto, indiciário, deixando sempre lacunas no objeto descrito que cabe ao leitor preencher e reconstituir. Como nos outros gêneros, também no ensaio Oswald destaca e arrasta o leitor para o círculo hermenêutico que constitui a obra de arte, cabendo a este, sempre, o papel de "ligar os pontos" e dar unidade à diversidade trazida à tona pela expressão. Esse estilo fragmentário de composição não cumpre apenas um papel formal, estilístico, mas é também a ferramenta ideal para o tratamento de temas que, se escritos segundo os modelos tradicionais de ensaio, demandariam talvez não um, mas vários livros, e que Oswald, no entanto, consegue abarcar com algo em torno de 70 páginas, em cada um dos ensaios. É, então, a concisão conseguida mediante recursos trazidos da poesia que permite a Oswald definir um recorte que vai de Ésquilo e Eurípedes a Sartre sem perder nem a coerência nem a agudez de raciocínio nem tampouco o essencial daquilo que compreende um ensaio filosófico: a reflexão original e profunda sobre os objetos, os percalços, os problemas e as possibilidades da existência humana. Não seria demais dizer que, assim como Borges fez o estupendo desbravamento do conto-ensaio, Oswald se arriscou no que parece ser o poema-ensaio.

\section{II - O SENTIMENTO ÓRFICO: PRINCÍPIO UNIFICADOR DA HISTÓRIA}

William Dray (1969) distinguiu entre filosofia crítica e filosofia especulativa da história. A primeira diz respeito à análise e ao criticismo epistemológico dos resultados e dos procedimentos da historiografia enquanto disciplina. A segunda, por sua vez, consiste na atribuição de um sentido à totalidade da história, oferecendo um modo sui generis de conexão e interconexão entre os eventos contingentes do passado, do presente e do futuro. Nossa hipótese é que, para além de alguns elementos 
esparsos que poderiam se encaixar nos reclames de uma filosofia crítica da história, o pensamento oswaldiano também se desdobrou numa filosofia substantiva da história. Se no primeiro caso o fio condutor era uma desconstrução do passado, no segundo o fio condutor é orientado para o futuro: trata-se da dimensão utópica que nunca esteve ausente do horizonte de Oswald.

Karl Löwith (1946), num de seus famosos estudos sobre a filosofia da história, caracterizou como fundamental a toda filosofia da história a determinação de um princípio unificador das sucessões históricas, de modo a dirigi-las segundo um sentido. Assim Deus, na teologia da história de Agostinho, ou a Razão, na filosofia da história de Hegel. No caso de Oswald de Andrade, esse princípio corresponde àquilo que o autor chama de sentimento órfico. Trata-se do sentimento existencial de abandono do ser no mundo (NUNES, 2011, p. 31) e que, como tal, corresponde diretamente à carência humana em encontrar um sentido e um significado para a vida, para a morte, para o sofrimento, para a injustiça. O sentimento órfico corresponde a um impulso original do homem: trata-se da dimensão irracional que está por trás de todas as crenças e que, por essa via, torna tão peculiar o vínculo do sentimento órfico às religiões em geral. Oswald volta o aguilhão de Voltaire contra ele próprio. A sentença voltairiana "A religião, quando não é malandragem, é loucura" é posta em chave declarativa mais do que irônica: de fato, toda religião foi composta fundamentalmente por uma dimensão louca, lúdica, poética que subjaz à criação e à crença depositada nos valores e dogmas religiosos. Afinal, o sentimento órfico corresponde "ao sentimento do sagrado que se oculta no homem, preso ao instinto da vida e ao medo da morte" (ANDRADE, 2011b, p. 255). É dele que brota toda criação de sentido por meio da qual o homem enfrenta a contingência e o caos. Com a constituição do sacerdócio, o sentimento órfico recebeu um mediador, um canalizador que durante séculos e nas mais diversas culturas dirigiu sua expressão e suas consecuções. Esse canalizador foi o que Max Weber (2004) chamou éticas de salvação. Mas, mesmo em épocas não religiosas, o sentimento órfico, que para Oswald é constituinte original da própria natureza humana, não cessa de existir: ele simplesmente ganha expressão em outras ordens da vida que não exatamente a religião: seja na Arte, sua esfera autêntica, seja na política ou na simples deificação de objetos da vida cotidiana ou mesmo dos objetos das compulsões pessoais que tomam forma na vida de cada um. O sentimento órfico é uma constante 
que, se não preside a história humana (como é o plano secreto da utopia de Oswald), está presente em todo momento no seu conjunto de forças atuantes, ainda que sob a égide de uma ordem da vida que lhe é estranha.

\section{III - O PENSAMENTO ANTROPOFÁGICO: A ORIGEM DA ANALOGIA}

Oswald, na condição de poeta-ensaísta, arrisca uma especulação filosófica da experiência histórica do homem como um todo, dividindo-a em três grandes fases e infundindo a elas um sentido e uma direção. Simplificadamente, trata-se do Matriarcado, que produziu uma cultura antropofágica, do Patriarcado, que produziu uma cultura messiânica e, por fim, numa espécie de síntese dialética, a conciliação de elementos de ambos os mundos numa era pós-patriarcal.

O matriarcado, para Oswald, é o mundo do homem natural, do qual o homem civilizado, produto da cultura patriarcal, é a antítese. A tese de Oswald, nesse sentido, pode ser posta no rol das tematizações que remontam à configuração do Direito Natural e, retrocedendo mais ainda, passando por Hobbes e chegando até Montaigne, Morus, Campanella, por meio da oposição entre natureza e civilização. É o "homem natural" que está diante dos olhos de Oswald quando este pensa um estágio anterior à constituição do homem civilizado. Seu propósito utópico, entretanto, não consiste em fazer o homem civilizado retroceder aos tempos primitivos e prescindir de todo o aparato material, técnico-científico, produzido e conquistado a tão duras penas e sacrifícios. O que ele pretende é levar ao homem civilizado, dotado com a técnica e a ascese, a visão de mundo e a metafísica do homem pré-patriarcal, seu modo de entender a morte, o sofrimento, a injustiça e os aspectos trágicos da existência e, principalmente, seu modo de se associar com outros e de assim constituir uma sociedade e/ou comunidade.

Segundo Oswald, o rito antropofágico, a devoração do inimigo (substituída no regime patriarcal pelo tornar o inimigo um escravo), exprime um modo de pensar a morte não como passagem para outra vida, mas como devoração. Ela diz respeito a uma concepção geral do que é vida, a um modelo geral de comunidade, a um específico modo de ser-junto e de estar em comunidade com outros, isto é, de relacionar o sentido de sua ação à de outros. O digerido é incorporado, e aquele que o digere está condenado a ser digerido um dia também: diante dos outros 
entes naturais e do processo imanente de vida e morte que os enlaçam, o homem natural constata o caráter devorador da vida e o expressa em rito.

Lançando mão de uma interpretação evemerista de uma lenda japonesa a respeito da origem do povo japonês, Oswald ilustra a passagem de uma sociedade matriarcal para uma sociedade patriarcal através da configuração do círculo totêmico. A princesa chinesa "Esplendor da Aurora" havia sido enviada como chefe de um conjunto de embarcações com suas aias às ilhas japonesas. Após naufrágio, a princesa Esplendor da Aurora e suas aias foram atiradas à costa de uma ilha habitada por antropoides, o macaco Saru. Segundoa lenda, da promiscuidade resultante entre as chinesas e o macaco Saru deu-se a origem dos japoneses. Seguese disso o assassinato do macaco Saru por seus descendentes e sua ulterior deificação totêmica.

Os frutos resultantes da promiscuidade entre chinesas e macacos, no acordar da sua primeira consciência, sentiram-se horrorizados e, querendo lançar um abismo entre a expressão humana adquirida e a sua origem animal, mataram o pai tribal que era o Macaco Saru (ANDRADE, 2011a, p. 151).

O Macaco Saru, objeto da ambivalência emocional dos filhos tanto admirado como odiado -, uma vez assassinado, "sobreviverá" na lembrança como culpa, que dará origem ao culto aos mortos, cristalizando assim sua deificação. Nascia o fundamento primeiro da cultura patriarcal, isto é, a representação da figura paterna como objeto de culto, veneração e culpa/dívida.

O estágio antropofágico da experiência humana só pode, então, ser anterior à configuração dos círculos totêmicos. Nele a vida é, como preconiza Oswald, encarada como devoração: incorporação contínua de forças que se embatem. Nele o ato antropofágico não assume a forma de rituais fixos, como passariam a existir com o culto totêmico. Ele é a simples incorporação a si do inimigo sacro, tal como repercutem em sua consciência nascente os processos naturais: toda a relação entre entes naturais é vista como um mútuo incorporar devorador.

1 Esse "sobreviver" do antepassado morto na consciência dos vivos dele descendentes se funda no que Freud chamou de "onipotência dos pensamentos". O homem primitivo vivia num estado de "supervalorização" do pensamento (FREUD, [s.d.], p. 107), no qual interpretava seus próprios estados internos como capazes de suplantar a distância no tempo e no espaço; em outras palavras, o homem primitivo não distinguia com clareza uma percepção atual de uma lembrança presentificada, de modo que sentia que podia abranger com um só ato de consciência o que estivesse afastado no tempo e no espaço. 
Aquilo que a antropologia e a sociologia da religião daquele tempo se esforçavam para explicar - a visão primitiva do mundo, a experiência humana naquilo que se julgava ser o ponto mais próximo de seu grau zero, de seu intrínseco contato com o mundo, com a natureza e todo o cosmos - por meio de complicados sistemas conceituais construídos mediante orientação metódica e investigação empírica, Oswald o fez por meio da criação de uma poderosa metáfora. A vida entendida como "devoração". A aproximação metafórica, diferentemente da científica, não torna o primitivo e a mentalidade pré-lógica num mero objeto "para o senhor Levy-Bruhl estudar" (ANDRADE, 2011c, p. 68). Ao contrário, ela restitui ao homem primitivo a senhoridade sobre sua própria visão do mundo, libertando-o da amarra interpretativa imposta pela assimetria da relação colonial que o teria colonizado e escravizado, mas não descoberto. Diante do absurdo da existência, diante da morte, do sofrimento e da injustiça do destino, diante, pois, da necessidade de dotar a vida com um sentido, o homem primitivo interpretou os processos caóticos e contingentes do mundo como uma múltipla e contínua incorporação de forças. O homem é devorado pela terra assim como ele próprio devorou sua presa. A devoração é o mediador entre vida e morte que, na chave dessa visão metafórica, não existem como oposições mas como singelos aliados: o devorado enriquece e alimenta aquele que o devora, sujeito a ser, também, a qualquer momento devorado. $\mathrm{O}$ princípio animista que equipara todos os entes do mundo como portadores de uma mesma substância anímica permite ao primitivo a constituição de uma visão unitária do ser, que percebe todos os processos do mundo e tudo o que nele há de caos e transformação, como a repetição básica de um mesmo princípio, a devoração, a deglutição de um ente por outro e a contínua incorporação entre devorador e devorado. O fundamental dessa visão de mundo préanimista é ter desenvolvido a analogia e a metáfora, e não o silogismo, como meio intelectual de domínio da realidade.

A configuração dos círculos totêmicos e do culto aos mortos desviou o ritual antropofágico de seu sentido original, mas ainda assim o ritual antropofágico era preenchido por um modo de pensar analógico e metafórico. Demoraria séculos para que, depois de constituído, o patriarcalismo engendrasse, através do helenismo socrático e da cultura romana, passando pela configuração do sacerdócio cristão ocidental, o silogismo como forma de pensamento que suplantaria e desvalorizaria a 
analogia, que se retiraria quando muito para os domínios periféricos populares, não virtuosos, não ascéticos - do conhecimento.

A passagem do pensamento analógico para o silogista corresponde à separação essencial das duas Weltanschauung [visão de mundo]: uma metafórica, livremente criativa, no sentido de que está pronta a oferecer sempre um novo ordenamento das coisas, entre elas e seus significados, e a outra analítica, cuja representação do mundo e das coisas está orientada para a subsunção do particular ao geral, sob um rígido controle que visa ao enquadramento do maior número de objetos particulares num mesmo conceito geral e almeja, assim, uma rede de semelhanças que despoje as coisas de seu potencial sempre renovável de significação, de suas diferenças intrínsecas e de suas semelhanças menos extensivas que permitiriam outras conexões que não aquelas do silogismo. É por isso que Oswald ataca a base do que lhe parecia ser um dos fundamentos do patriarcado ou, pelo menos, uma de suas principais figuras: Sócrates. É de Sócrates que brotam as fontes da lógica aristotélica e de toda ulterior depreciação das artes e da metáfora como forma de conhecimento. A utopia de Oswald, consistindo numa síntese dialética entre matriarcado e patriarcado, entre cultura antropofágica e cultura messiânica, é casar as duas posturas cognitivas numa mesma expressão estética. O poemaensaio de Oswald parece ser, inclusive, resultado dessa tentativa, já que une argumentação lógica com uma retórica analógica e metafórica. Pois não é com uma "metáfora lancinante" que Oswald acusa Sócrates, patrono da Lógica, de perseguir e calar a Arte? - "Funciona aí o primeiro DIP" (ANDRADE, 2011a, p. 158). ${ }^{2}$

\section{IV - PATRIARCADO E CULTURA MESSIÂNICA - O APRISIONAMENTO DO SENTIMENTO ÓRFICO}

O fato fundamental da Era do Patriarcado, para Oswald, corresponde ao aprisionamento eà monopolização administrativa do sentimento órfico pelo sacerdócio ocidental. A ascensão e a legitimação da classe sacerdotal, por sua vez, estão ligadas à composição de uma visão de mundo cujos princípios podem retroceder ao mundo grego e atingem seu ápice na cristandade medieval.

2 A abreviatura DIP se refere a órgão de Estado que, entre os anos de 1939 a 1945, funcionou como instância de controle e censura de produções artísticas e culturais no Brasil. 
Nas primeiras tribos humanas, diz Oswald, "desligado o ato da geração do ato do amor, não é possível drama algum ante os direitos da mulher à sua existência amorosa" (ANDRADE, 2011a, p. 154). É o contrário do que ocorre no domínio do Patriarcado, onde ressoa a vingança do filho sobre a mãe adúltera e o qual, se começa com Ésquilo, atinge seu ápice com Shakespeare e atravessa Eurípedes, Racine, Goethe e Ibsen, na forma do drama "da inconformação dos filhos ante a constância libertária dos pais amorosos. É o drama da herança e da propriedade privada” (p. 155).

Se a reconstituição de um estado matriarcal primitivo estava aquém das forças das ciências paleontológicas e arqueológicas do período de Oswald, sua existência e derrogação eram para ele assinaladas na literatura grega, especialmente nas tragédias de Ésquilo, com destaque para a Oréstia. Nessa obra, Orestes, filho de Agamêmnon e Clitemnestra, vinga a morte de seu pai, assassinado pelo amante de Clitemnestra enquanto voltava da guerra do Peloponeso. Orestes, em vingança ao pai traído, assassina a própria mãe. A partir de então, Orestes é perseguido pelas Erínias, personificações da vingança encarregadas de punir os crimes de sangue, especialmente o mais grave deles, o matricídio. Levado a julgamento presidido por Palas Atena, Orestes, defendido por Apolo, acaba absolvido depois de empate entre os votos dos juízes. O voto de Palas Atena decidiu pelos direitos do Pai, absolvendo Orestes do crime de matricídio; as Erínias, convencidas da própria inutilidade, sujeitam-se às leis do Estado nascente, esse regulador e monopolizador da vingança, cujo fundamento está na herança paterna e em suas reivindicações. Daí o caráter e o status de fundador que a Oréstia ocupa diante de toda a literatura ocidental (CARPEAUX, 2012, p. 55) e, mais do que isso, o fato de corresponder a um dos documentos fundadores da Revolução Patriarcal, que derradeiramente pôs fim às sociedades de direito materno.

Numa hipérbole para lá de ousada, Oswald chega a dizer que toda a história da literatura, de lá para cá, até Sartre, foi expressão estética de um "milenário comício da servidão" (ANDRADE, 2011a, p. 156), isto é, toda a história da literatura ocidental pode ser interpretada como expressão da constituição, da legitimação e da dramatização da autoridade paterna e do princípio patriarcal de estruturação do poder. Nesse comício milenar, um dos palanques principais foi erguido por Sócrates. Repare-se que não apenas a expressão metafórica é desvalorizada em virtude da silogista mas também, e portanto, a forma do conhecimento é submetida ao ideário Patriarcal. A moral socrática estabelece ainda os limites do belo 
e também do amor. A estes Sócrates vincula a honestidade e a eleição como pressupostos irrevogáveis, condenando cabalmente o erotismo da Vênus popular, em que se dá "preferência ao corpo sobre a alma" (p. 156). Ora, nessa concepção socrática de amor, fundada na eleição, Oswald identifica não apenas a base do ódio de classe, como também o fundamento que legitima a servidão e estabelece como ético o espírito servil: as virtudes socráticas são identificadas às virtudes do rebanho: 0 piedoso, o justo, o continente, o prudente. A filosofia socrática, assim, funda a base de justificação e conservação do escravo satisfeito, no qual "reside o fundo catequista de todas as covardias sociais e humanas" (p. 159). Com Sócrates, a cultura ocidental adentra a seu fundamental estado de negatividade, que caracteriza o homem civilizado. A expressão dessa negatividade funda um dualismo entre natureza e homem, entre corpo e alma, terra e céu. E é Sócrates, segundo Oswald, quem lança os primeiros fundamentos filosóficos desse dualismo: "Contra o politeísmo, ele lança o Deus único. Contra o sentido precário da vida de Heráclito, ele lança a imortalidade da alma. Contra a visão conflitual do mundo de Empédocles, lança a imutabilidade do Bem" (p. 160). A negação da própria natureza e a do mundo se dão pelas vias da orientação para um além ao qual se dirigem as expectativas de salvação. Está trilhado o caminho para a constituição do sacerdócio e de uma cultura que Oswald chamou de "messiânica".

Nesse contexto, o pensamento de Sócrates é situado entre duas grandes tradições intelectuais que, no entendimento de Oswald, correspondem a duas longas fases de desenvolvimento do Patriarcado: trata-se da fase grega e da cristã. Na fase grega, há a passagem decisiva do direito materno ao paterno (que por eras conviveram), a consequente instituição da escravidão, ${ }^{3}$ do Estado, a justificação aristocrática da escravidão, a ligação entre geração e amor, entendido este agora como eletivo, e, sobretudo, a sobreposição da alma sobre o corpo, do eterno sobre o efêmero, do ser sobre o devir (a imortalidade da alma e a imutabilidade do bem); na fase cristã, há a introjeção decisiva da promessa messiânica como suporte e justificação da condição de escravo (de cárita, de sofredor, de dominado), bem como da instituição da monogamia e da obediência às leis (aceitação do destino) como valores indispensáveis à salvação religiosa.

A valorização ética da obediência como expressão máxima da virtude e do direito à compensação pós-morte enuncia um aspecto fundamental

3 Segundo Oswald, o abandono do rito antropofágico, que consiste na devoração do inimigo sacro, é correlato ao ato de fazê-lo seu escravo. 
da "moral de escravos" e da educação patriarcal que Oswald queria combater. Nas páginas de Fédon, podemos ver a justificativa de Sócrates para sua aceitação da cicuta: é sua ideia da imortalidade da alma que serve de fundamentação a seu conformismo e, desde que cumpra e acate a lei, poderá gozar no pós-morte a compensação aos bem-aventurados. Em longo diálogo com Símias, nas vésperas de sua condenação à cicuta, diz Sócrates:

A alma se assemelha ao que é divino, imortal, dotado da capacidade de pensar, ao que tem uma forma única, ao que é indissolúvel e possui sempre do mesmo modo identidade: o corpo, pelo contrário, equipara-se ao que é humano, mortal, multiforme, desprovido de inteligência, ao que está sujeito a decompor-se, ao que jamais permanece idêntico [...] (PLATÃO, 1983, p. 84).

\section{E, em sequência, continua Sócrates,}

Mas então a alma, aquilo que é invisível e que se dirige para outro lugar, um lugar que lhe é semelhante, lugar nobre, lugar puro, lugar invisível, o verdadeiro país de Hades, para chamá-lo por seu verdadeiro nome, perto do Deus bom e sábio, lá para onde minha alma deverá encaminhar-se dentro em breve, se Deus quiser (PLATÃO, 1983, p. 85).

E, por fim, Sócrates estabelece a relação entre o cumprimento do dever moral, a valorização ética da obediência e a compensação devida no futuro pós-morte: daí sua inabalável aceitação da cicuta. É na resposta a Críton, que lhe pergunta o que fazer com seu corpo depois de morto, que Sócrates estabelece derradeiramente tal relação. Diz ele a seus discípulos, entre eles o próprio Críton:

Não há meio, meus amigos, de convencer Críton de que o que eu sou é este Sócrates que se acha presentemente conversando convosco e que regula a ordem de cada um de seus argumentos! Muito ao contrário, está persuadido de que eu sou aquele outro Sócrates cujo cadáver estará daqui a pouco diante de seus olhos; e ei-lo a perguntar como me deve enterrar! E quanto ao que desde há muito venho repetindo - que depois de tomar o veneno não estarei mais junto de vós, mas me encaminharei para a felicidade que deve ser a dos bemaventurados - tudo isso, creio, eram para ele vãs palavras, meras consolações que eu procurava dar-vos, ao mesmo tempo que a mim mesmo (PLATÃO, 1983, p. 123).

Como nota Oswald, a personalidade "Sócrates" é entendida, assim, como algo fora do corpo e que não precisa deste para ser o que é. Esse Sócrates que figura como elemento central dos diálogos platônicos já tinha delineado, assim, a base da visão de mundo ocidental fundada na ideia 
de um deus único transcendente à ordem, da imortalidade da alma, de sua supremacia sobre o corpo e, sobretudo, na valorização da obediência como meio de compensação futura às desgraças e misérias do presente; isto é, a justificação metafísica da obediência.

No que diz respeito ao cristianismo primitivo, Oswald destaca o desenvolvimento da questão social em Roma e a ênfase sobre a salvação. Ele destaca como o cristianismo, em seu início, adquiriu o significado de uma "revolta de escravos", num sentido mais prático do que propriamente moral. A disseminação do cristianismo encontrou condições ótimas de realização no seio do Império Romano, abarrotado de tipos sociais escravizados e/ou mantidos sob pesada exploração dos setores aristocráticos do Império. A escrita dos evangelhos trouxe, em seu escopo, além da identificação de Cristo com o sofrimento impingido a grande parte da população submetida pelo Império Romano (tratavase de um "deus carpinteiro"), como ainda a expectativa explosiva de uma ideia avassaladora, a parúsia: a volta vingativa do messias para punir os perpetradores de sofrimento e redimir os sofredores.

\begin{abstract}
A parúsia era a volta vingadora do Messias ressuscitado e subido aos céus, volta que liquidaria as injustiças sociais e destroçaria os tiranos do mundo. [...] Evidentemente só uma religião que prometia justiçar interessaria àquela imensa e confusa multidão de escravos reunidos pelo poderio romano. [...] Os escravos reconheciam-se, nele se miravam e facilmente criam que, subido aos céus, ele voltaria para vingá-los dos ultrajes terrenos. O suplício da cruz era tão natural e comum que, num só dia, Tito fizera crucificar dois mil judeus. [...] Cristo era do mesmo sangue, da mesma carne e do mesmo destino que seus irmãos cativos. O sentimento órfico açulava as esperanças da parúsia (ANDRADE, 1992, pp. 238-239).
\end{abstract}

A ideia da Parúsia tornou-se o vetor que canalizou o sentimento órfico em direção às agitações sociais que ameaçavam o Império. Sua especificidade era a promessa de justiça neste mundo em consequência do retorno de Cristo. $\mathrm{O}$ ambiente de fervor religioso e justiceiro, em cujos êxtases atuavam a imagem de um "deus que trazia em si os estigmas da dor humana”, suscitava a normal ação repressiva por parte do Império. Segundo Oswald, foi o teólogo Clemente de Alexandria o responsável pela transferência da expectativa de compensação neste mundo para um mundo situado no além-túmulo, para a vida pós-morte e, portanto, pela nova significação decisiva da Parúsia. Esta, assim, passava a estar totalmente restrita ao dualismo de uma vida de injustiça travada na terra 
e à expectativa de redenção - justiçamento - numa futura vida celeste. E que Oswald, metaforicamente, chama de "estorno ideológico".

Clemente é o responsável por esse estorno ideológico que transferiu para a vida futura as vantagens fulminantes da parúsia. Foi ele o primeiro sacerdote cristão a admitir a possibilidade oficial de um rico penetrar impune no reino dos céus. O cristianismo deixava com ele a sua missão revolucionária e social (ANDRADE, 1992, p. 40).

É a partir daí que a revolta cristã se esvai do domínio da ação e se torna impotente e ressentida: ela se moraliza. Com esse "estorno ideológico" estava fundada, para Oswald, a raiz metafísica que daria sustentação ao sacerdócio como herdeiro da burocracia do Império, após a oficialização do cristianismo decretada por Constantino.

Antes disso Paulo já havia insistido no estabelecimento da monogamia ao escravo como esteio de sua dignidade - e, portanto, sua possibilidade de salvação futura. A ideia de que todos são iguais em Cristo, sugerindo uma natureza humana transcendente às diferenças locais e étnicas, é um aspecto que, a partir da modernidade renascentista, ganharia um desdobramento secular na forma do Humanismo, fenômeno cujo papel utópico foi acentuado por Oswald em A marcha das utopias.

Outro passo importante, para Oswald, foi dado por Agostinho: por um lado o internacionalismo da "Cidade de Deus" repercute diretamente na estrutura do poder político local (reinos e condados), na medida em que interpõe a autoridade sacerdotal como mediadora de um poder universal que submete a todos os povos (unidade da cristandade). Além disso, sua teoria do arbítrio e da interioridade tornar-se-iam as fontes da subjetividade autônoma que é enfatizada por toda a tradição intelectual Greco-cristã. A partir daí, o sacerdócio assumiria o papel de sentinela ativa do arbítrio. Deixando de participar de sua salvação religiosa, não podendo mais intervir em seu destino religioso, ao crente resta a fé no absurdo e a confiança irrestrita nos desígnios misteriosos de Deus; ora, o sacerdote é o funcionário eclesiástico a serviço de uma tradição, da observação dos costumes e regras de uma ordem estabelecida: e, com a doutrina agostiniana da predestinação, o sacerdócio constitui a fonte de autoridade que ratifica o absurdo em sagrado - desaparecendo o carisma profético, é a autoridade sacerdotal que garante que permaneça inviolável a crença nos dogmas uma vez revelados; é nela que se deposita a certituto salutis e, portanto, também a justificação da obediência. 
Ockham (1985), nessa linha de raciocínio, levaria a ideia de um deus transcendente a seus limites, elevando ao infinito a causalidade divina e reduzindo todas as causas a uma só: Deus. Expressava-se, assim, em seu mais alto grau, a ideia de um deus transcendente à ordem cosmológica, criador dessa mesma ordem e que dispõe de cada detalhe de suas relações. "Tudo o que não procede de Deus como sua causa eficiente é incausado, e o que é incausado é Deus. Logo, todo outro ser procede de Deus como sua causa eficiente [...] Tudo fora de Deus foi feito por ele." (OCKHAM, 1985, p. 404). Diante de um deus como esse, ao crente cabe a aceitação e a entrega total à sua vontade, sempre incognoscível de antemão. "Deus pode fazer o que quiser. Para ele não há compreensão nem crítica. É a entrega pura e simples do escravo." (ANDRADE, 2011a, p. 170). No âmbito desse entendimento, a História, dissimulando o arbítrio na providência divina absoluta, torna-se o romance de Deus - um tirano que pode fazer o que bem entender com suas personagens e criaturas, e dispor de cada mínimo detalhe de seu ambiente, de suas vidas e do cosmos como um todo.

A Tomás de Aquino coubea consagração do sacerdócio como mediador do direito divino dos reis. Utilizando a técnica poética da colagem, Oswald elabora um silogismo com as citações que, sem dar referência, retira da obra de Tomás de Aquino:

\footnotetext{
"Para a perfeita regularização da vida humana, é preciso a instituição de uma lei, superior às leis natural e humana, que ajuste os atos do homem para seu fim transcendente". "Corresponde à lei induzir o homem ao cumprimento do seu dever." "Como a lei emana de um só Rei para um só reino, e como o gênero humano constitui um reino para um só cetro, o cetro de Deus, só há uma lei divina" (AQUINO apud ANDRADE, 2011a, pp. 171-172).
}

Tomás, assim, dava expressão política à sua posição ontológica, que pretendia "arrancar o ser do fluir" e que entendia Deus sob os atributos da imobilidade, da eternidade; para Tomás, Deus é imóvel, eterno, existe por si mesmo e sempre, é simples e alheio a qualquer divisão entre potência e ato; ele é exclusivamente ato (AQUINO, 1985, pp. 73-76). E, nessa operação intelectual sumarizada no silogismo poeticamente arranjado por Oswald, ele reconhecia a elaboração de um conceito de Humanidade como derivado da universalização da subjetividade cristã.

Segundo a leitura do racionalismo ocidental empreendida por Oswald, seria já na aurora do período moderno que se daria o início da derrogação intelectual do patriarcado, processo em contradição com 
sua perpetuação potencializada na base material. E é na própria teologia luterana e protestante que se podem verificar as versões discursivas dessa contradição: já no próprio luteranismo se observa o movimento que, por um lado, golpeia intensamente o sacerdócio e, por outro, introduz uma valorização religiosa do trabalho no mundo que potencializaria e redirecionaria a ascese extramundana do monasticismo sacerdotal para o êxito na vida profissional, requerendo-o também para o domínio dos leigos. Com Lutero, tem-se a liquidação do celibato sacerdotal, subtraindo-lhe, diz Oswald, a sua vestalidade (ANDRADE, 2011a, p. 178), a sua pureza, a sua castidade, enfim, o elemento de virtuose religiosa que aristocratizava a classe sacerdotal; e o protestantismo ascético, especialmente em sua versão calvinista, chega ao ponto de prescindir por completo da necessidade de culto, minando as fontes e as premissas da constituição de qualquer sacerdócio. E, se não bastasse, é o próprio Lutero que, estabelecendo uma concepção de salvação religiosa fundada na valorização ética do trabalho, plantaria a semente do ascetismo que, em seus ulteriores desenvolvimentos, reclamaria assim uma vitória do “negócio" sobre o "ócio sagrado" dos sacerdotes.

Paradoxo semelhante Oswald observa em Descartes. O método da dúvida reorientou a operação cognoscitiva para fora do dogma e por isso contribuiu - ao lado da Reforma - para a fundamental quebra do monopólio interpretativo até então exercido pela Igreja e pelo poder papal, que tinha sempre a última palavra sobre qualquer questão pendente acerca dos mistérios da vida, do mundo, do céu, da terra e da morte. E isso significou o começo de um processo ambíguo de liberação relativa da razão em relação à fé e desta, por sua vez, quanto ao direcionamento e aprisionamento do sentimento órfico pelo sacerdócio. Mas, por outro lado, o mesmo Descartes repete o conceito medieval de Deus, presente na própria estrutura do Cogito, sobre a qual Oswald evidenciava os laços com a dimensão do foro interior agostiniano. "Porque já está em Agostinho a inteira descoberta do Cogito." (ANDRADE, 2011a, p. 180).

E, em direção contrária à filosofia messiânica do patriarcado, antes de Descartes vinha o Renascimento, cuja retomada, mesmo que anacrônica e deformada, dos valores clássicos, permitiu uma revalorização do corpo, da sensibilidade, da sensualidade que intensificou não apenas o potencial da expressão estética do mundo ocidental, como também tendeu a reequilibrar a desproporcional hierarquia alimentada desde Sócrates entre alma e corpo. A isso se soma a ascensão e a consolidação 
da burguesia cujo afã aquisitivo havia sido ratificado pela teologia protestante; a universalização da forma monetária como linguagem macabra que, no esquema trágico de Georg Simmel, tornar-se-ia o significante universal para todas as coisas e objetos do mundo; a cidade e seu cosmos de mobilidade comercial e fiduciária, que colocaria abaixo de si o poder eclesiástico a partir de então domado pelo Estado, que por sua vez se estruturava na recuperação do Direito Romano clássico como fundamento legal para a propriedade privada (ANDERSON, 1998, p. 23). $\mathrm{E}$, com tudo isso, todo o ambiente que recuperaria a ascese extramundana do monge católico e a reorientaria em relação ao mundo, ao trabalho e à transformação terrena desse mundo e da vida na terra (ANDRADE, 2011a, pp. 176-177).

E, na condensação poética desses abismais acontecimentos históricos, Oswald salientaria aquele que, não apenas situado na contramão da cultura messiânica, levaria a um horizonte para além do patriarcado, recuperando para o homem civilizado um medidor de valor não especular: o homem natural encontrado nos trópicos e que foi o objeto da curiosidade e também da crueldade europeia na era dos descobrimentos; ora, é a descoberta do outro, de formas culturais e de interpretações da vida, da morte, do sofrimento e da injustiça totalmente dissonantes em relação ao sentido único monopolizado pela tradição cristã, que está na base da constituição das utopias que dariam ensejo ao Humanismo do século XVI.

Com a crescente derrogação crítica do sacerdócio e com o processo de secularização subjacente, o sentimento órfico, longe de se extinguir, é liberado e sujeito a desaguar-se em outros âmbitos da vida. Reprimido na esfera religiosa pela crítica exaustiva ao conceito de Deus, reaparece pulsante na ascensão político-emocional de massa, em torno de figuras teocráticas como Hitler, Mussolini, Lênin (ANDRADE, 2011b, p. 234). Esse sentimento, enquanto disposição humana para "crer no absurdo", liberado da grade sacerdotal, transita vulnerável nas esferas da vida cotidiana, pronto a deificar e a se submeter a esferas estranhas à sua autenticidade criativa. Esse sentimento lúdico-religioso que está na base de toda crença - e, portanto, de toda dominação legítima, já que esta procura sempre se fundar na crença por parte dos dominados - pode, assim, ser colonizado a serviço de novas orientações carismáticas em torno de ideais políticos (como o nazismo e o fascismo encarados como fenômenos religiosos) ou ainda se dissolver num sistema dentro do qual o trabalho e o consumo ganham qualidades de culto religioso e, mais especificamente, de um culto 
religioso que funciona sem dogma e incessantemente. ${ }^{4}$ É na recuperação metafórica da antropofagia que Oswald construirá um sentido utópico para o desfecho da derrocada do patriarcalismo. Assumindo a situação da sociedade ocidental e da enorme potencialidade erguida pelo avanço técnico, Oswald anunciava um futuro pós-patriarcal que, apoiado na possibilidade técnica de um processo produtivo que libere o homem do trabalho, habilite a humanidade tanto para o exercício e para a partilha do ócio: o sentimento órfico, liberado tanto dos compromissos religiosos quanto da disciplina econômica da racionalidade instrumental capitalista, seria reapropriado em sua dimensão autêntica: a da criação artística e intelectual. A reapropriação do sentimento órfico, sua canalização para a arte e para a partilha do ócio: eis as máximas da utopia de Oswald.

\section{V - CONSIDERAÇÕES FINAIS - UTOPIA ANTROPOFÁGICA E FILOSOFIA DA HISTÓRIA}

Como pudemos observar ao longo desse texto, os ensaios de Oswald trazem elementos de uma filosofia da história própria, que o autor desenvolveu em consonância a um projeto político de emancipação e a uma antecipação especulativa do futuro. Toda a história humana é, então, posta sob a perspectiva do desenvolvimento de um princípio comum que atravessa a experiência humana: o sentimento órfico. Mais ainda, a própria história ocidental é ela mesma vista como o direcionamento do sentimento órfico em duas fases distintas: uma matriarcal, antropofágica, criadora do modo de pensar analógico, outra patriarcal, messiânica, criadora do modo de pensar silogístico. No matriarcado, a estruturação comunitária não se baseia na paternidade, já que esta não pode ser determinada com precisão. Nele não há nem complexo de castração nem

\footnotetext{
4 Walter Benjamin, num fragmento tardiamente publicado mas hoje bastante conhecido, já em 1921 entendia o capitalismo do ponto de vista do modo como, enquanto sistema, administra o sentimento religioso: a secularização, assim, diz respeito tão somente à dissolução dos dogmas religiosos, perseverando a disponibilidade do sentimento que dispõe o homem à realização dos cultos. O capitalismo, dessa forma, é entendido ele mesmo como um fenômeno essencialmente religioso: “[...] o capitalismo é uma religião puramente cultual, talvez a mais extrema que jamais tenha existido. Nada há nele senão uma relação imediata com o significado do culto; ele não conhece nenhum dogma especial nem teologia. O utilitarismo ganha, sob esse ponto de vista, sua coloração religiosa. Um segundo traço do capitalismo interliga-se com esta concreção do culto: a duração permanente do culto. O capitalismo é a celebração de um culto sans rêve et sans merci" [sem sonho e sem piedade] (BENJAMIN, 2011, p. 2).
}

Remate de Males, Campinas-SP, v. 37, n. 1, pp. 323-344, jan./jun. 2017 
complexo de Édipo, desaparecendo a hostilidade contra o pai e também a ulterior interiorização da imagem do pai como princípio de autoridade das regras sociais. Numa comunidade na qual o indivíduo é visto e entendido como filho da comunidade e não de um pai em particular, não há espaço para a herança nem, portanto, para a propriedade privada. Somente com a monogamia imposta à mulher a partir do domínio patriarcal e com a fixação do parentesco a partir da paternidade é que a herança se tornou fundamento da posse; do mesmo modo, apenas quando o homem deixou de comer seu inimigo para torná-lo seu escravo é que se fundou um Estado de classes. A partir desses marcos da Revolução Patriarcal - a fixação da paternidade, a propriedade privada e a escravidão - desenvolver-se-ia toda a história do racionalismo ocidental, marcado desde então pelo problema da liberdade, inexistente no matriarcado justamente porque tal problema só existe como reivindicação quando o homem passa a escravizar o próprio homem (ANDRADE, 2011a, p. 202).

Ora, é na solução do problema da liberdade que Oswald destaca a importância do messianismo na constituição da cultura ocidental, já que sem a ideia de uma vida futura (fundada na ideia da imortalidade da alma, da bem-aventurança, da imutabilidade do bem) redentora do sofrimento nesta vida dificilmente o escravo teria suportado a condição que lhe foi impingida. O problema da liberdade, na ótica patriarcal-messiânica, ganhou sempre uma fundamentação legitimadora das posições de classe através do redirecionamento das esperanças escatológicas para a vida no além-mundo e, mais importante, condicionando a salvação ao cumprimento dos preceitos que perpetuam a relação de dominação iniciada desde a revolução patriarcal: a valorização ética da obediência e o amor monogâmico e eletivo - ao menos da parte feminina.

O confronto do homem civilizado com aquele do qual é a antítese e em relação ao qual se encontra em contínuo estado de negação marcou o cruzamento daquela outra fase da história que, com o predomínio crescente da cultura patriarcal, havia sido relegada ao esquecimento. A nudez, o sensualismo e o ócio então redescobertos ali fariam daquele encontro uma "esquina da história" (ANDRADE, 2011b, p. 234) na qual se confrontariam com o ascetismo e o formalismo que passariam a ganhar ainda mais destaque com a valorização moral e religiosa do trabalho, implementada por Lutero e pelo protestantismo ascético em geral. Se, no período medieval o ócio sobrevivia ainda como privilégio de classe, durante o período posterior à Reforma suas exigências seriam cada vez 
mais suplantadas pelas exigências do negócio, da negação do ócio, do trabalho.

Para Oswald, corresponde ao nascimento das utopias (Morus e Campanella) a ligação ambivalente entre as duas visões do ócio, a positiva e a negativa. Elas surgem no mesmo ímpeto de valorização ascética do trabalho mundano. Entretanto, se dirigem não exatamente contra o ócio, mas contra o ócio de classe, privilégio de sacerdotes e aristocratas até o período medieval. As utopias conciliam, assim, ascetismo e igualitarismo, trazendo em si a nítida percepção de que a conquista do ócio só era possível por meio de sua negação, do negócio e do trabalho. "De modo que, sob o signo das Utopias, é todo um evangelho de trabalho ativo, e ao mesmo tempo de igualitarismo, que se constrói e afirma nos sonhos de Morus e de Campanella." (ANDRADE, 2011b, p. 238).

Com isso, o problema da liberdade passou a ganhar uma nova corrente de fundamentação, que desde então guiou-se não pela justificação das posições de privilégio a partir da postulação de uma vida futura, mas pela redenção dos sofrimentos nesta vida através partilha comunitária do ócio - e, portanto, também do trabalho. A grande contribuição dos primeiros utopistas foi a percepção de que o igualitarismo do ócio só pode ser conseguido através do trabalho.

É um paradoxo profético esse de ter a descoberta do homem ocioso da selva americana trazido à luz e à ação grandes propósitos de organização social e de trabalho. Como se os dois escritores do Renascimento houvessem compreendido que somente através das conquistas técnica e do trabalho humano fosse possível, mais tarde, a reconquista do ócio para que o homem nasceu (ANDRADE, 2011b, p. 238).

Ora, é essa reconquista do ócio que divisa toda a interpretação da história implementada por Oswald, já que ela é que poderia liberar o potencial criativo do sentimento órfico, agora aprisionado nos cultos do capitalismo. A constituição de uma terceira fase da experiência humana, que antropofagicamente deglutiria a técnica - o fator negativo - e a transformaria em fator positivo, que conciliaria o regime comunitário matriarcal com o potencial técnico-produtivo da era patriarcal, possibilitaria, enfim, a liberação progressiva dos homens em relação ao trabalho, reapoderando-os do ócio primitivo e de sua autêntica realização existencial: a expressão estética preenchida pelo sentimento órfico. 


\section{REFERÊNCIAS BIBLIOGRÁFICAS}

ANDERSON, Perry. Linhagens do estado absolutista. São Paulo: Brasiliense, 1998.

ANDRADE, Oswald de. O antropófago. In: . Estética e política. São Paulo: Globo, 1992, pp. 233-284.

ANDRADE, Oswald de. A crise da filosofia messiânica. In: . A utopia antropofágica.

São Paulo: Globo, 2011a, pp. 138-215.

ANDRADE, Oswald de. A marcha das utopias. In: A utopia antropofágica. São Paulo: Globo, 2011b, pp. 220-298.

ANDRADE, Oswald de. Manifesto Antropófago. In: . A utopia antropofágica. São Paulo: Globo, 2011c, p. 67-74.

AQUINO, Tomás de. Compêndio de Teologia. Seleção de textos. São Paulo: Abril Cultural, 1985, pp. 69-101. (Os Pensadores)

BENJAMIN, Walter. Capitalismo como religião. Revista Garrafa, noㅜ 23, 2011, pp. 1-4.

CAMPOS, Haroldo. Serafim: um grande não-livro (Prefácio). In: ANDRADE, Oswald de. Serafim Ponte Grande. São Paulo: Ed. Globo, 2005, pp. 5-28.

CÂNDIDO, Antônio. Vários escritos. São Paulo: Ed. Duas Cidades, 2004.

CARPEAUX, Otto Maria. História da literatura ocidental, vol. 1. São Paulo: Leya, 2012.

DRAY, William. Filosofia da história. Rio de Janeiro: Zahar, 1969.

FREUD, Sigmund. Totem e tabu. Rio de Janeiro: Imago, s/d.

HELENA, Lúcia. Totens e tabus da modernidade brasileira: símbolo e alegoria na obra de Oswald de Andrade. Rio de Janeiro: Tempo Brasileiro, 1985.

LÖWITH, Karl. The Theological Background of Philosophy of History. Social Research, v. 13, no 1,1946 , pp. 51-8o.

NUNES, Benedito. Antropofagia ao alcance de todos. In: ANDRADE, Oswald. A utopia antropofágica. São Paulo: Globo, 2011, pp. 7-56.

OCKHAM, Willian. Obras selecionadas. São Paulo: Abril Cultural, 1985, pp. 386-404. (Os Pensadores)

OLIVEIRA, Vera Lúcia de. Poesia, mito e história no Modernismo Brasileiro. São Paulo: Ed. UNESP, 2002.

PLATÃO. Fédon. Platão. São Paulo: Abril, 1985, pp. 56-126. (Os Pensadores) 


\section{A Filosofia da História de Oswald de Andrade - 344}

WEBER, Max. Os tipos de dominação. In: . Economia e sociedade. São Paulo: UnB, 2004, pp. 139-198.

WEBER, Max. Sociologia da religião. In: Economia e sociedade. São Paulo: UnB, 2004, pp. 249-418. 